\title{
"Nieja oczy otwieram". Etyczne czytanie i Morfina Szczepana Twardocha
}

Michał Koza

TEKSTY DRUGIE 2016, NR 4, S. 340-357

DOI: $10.18318 /$ td.2016.4.22

\section{Odwrót od etyki i jej inna obecność}

Projekty etycznego czytania', formułowane co jakiś czas przez badaczy nie tylko w ramach tzw. ethical turn ${ }^{2}$, napotykają na wielorakie trudności, z których najpoważniejsze zdają się dotyczyć współczesnej kondycji podmiotowości (gdzie już sama sprawczość „ja” okazuje się problematyczna) i nowego typu doświadczenia, w którym miałby zaistnieć fenomen etyczny (skoro, jeśli wierzyć Nietzschemu, ,zjawisk moralnych nie ma wcale, istnieje

1 Zasadniczo odróżniam tutaj "etyczne czytanie” jako lekturę w perspektywie kategorii etycznych od "etyki czytania", czyli aksjologii samego aktu interpretacji. Z drugiej strony, z powodów, których nie da się niestety tutaj szerzej rozwinąć, nie należy tych dwóch perspektyw zbyt ostro oddzielać.

2 Na temat zjawiska zwrotu etycznego por. np. A. Burzyńska Dekonstrukcja, polityka i performatyka, Universitas, Kraków 2013, s. 50-67; M.P. Markowski Zwrot etyczny w badaniach literackich, „Pamiętnik Literacki" 2000 z. 1, s. 239-244.

3 W kontekście etycznym w syntetyczny sposób omawia ją np. M. Gołębiewska Wybór etyczny według Kierkegaarda a tożsamość w kulturze medialnej, "Teksty Drugie” 2002 nr 3, s. 152-156.

\section{Michał Koza -}

mgr, doktorant Katedry Antropologii Literatury Wydziału Polonistyki UJ. Autor tekstów dla serwisu Popmoderna, publikował m.in.

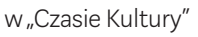
i „Ruchu Literackim”. Interesuje się związkami filozofii i literatury, teoriami podmiotowości i interpretacji. Kontakt: michal. koza@outlook.com 
tylko moralny wykład zjawisk"4). Z pewnością ten rodzaj lektury uczestniczy w ponowoczesnym losie aksjologii w ogóle. Destabilizacja całościowych projektów antropologicznych, opisywana przez uczonych najróżniejszych orientacji, m.in. Zygmunta Baumana, Charlesa Taylora, Richarda Rorty'ego $^{5}$, a także polskich badaczy ${ }^{6}$, doprowadziła do zaniku bądź przynajmniej do znacznego osłabienia tradycyjnych sposobów literackiej artykulacji doświadczenia moralnego. Również w literaturze zaszedł proces, który w szerszej, kulturowej perspektywie polegał na wyciszeniu wielkich etycznych narracji, opierających swój autorytet na metafizycznym fundamencie. Zwłaszcza krytyka żywi obecnie głęboki sceptycyzm wobec wszelkich prób tradycyjnego „moralizowania” - i jak zauważyła Anna Nasiłowska we wstępie do numeru „Tekstów Drugich” w całości poświęconego relacji etyki i literatury:

Sytuację dzisiejszą, po przełomie, można by skwitować krótko: role się odwróciły, a historia wzięła odwet na etyce. Wszelkie próby posługiwania się dawnym moralistycznym typem argumentacji brzmią dziś fałszywie i odbijają się czkawką demagogii. Jeśli ktokolwiek usiłuje w warunkach demokracji w prosty sposób sprowadzić wybory polityczne do etyki dokonuje manipulacji, co samo w sobie jest postępowaniem nagannym z etycznego punktu widzenia. ${ }^{7}$

Utożsamianie tego zjawiska z całkowitą eliminacją pytań moralnych byłoby jednak zbyt pochopne, ponieważ funkcjonują one na innych zasadach i w innych formach - zwykle dalekich od kategoryczności i formułowanych nie wprost. Mimo ponowoczesnych przemian ethical reading nie znika ze sceny literaturoznawczej, wręcz na nią powraca w wysiłkach nowego określenia już nie tyle właściwego systemu, mającego ująć w aksjologiczną strukturę interpretowany tekst, co samego sposobu stawiania tego rodzaju pytań. Stało się tak nie tylko w ramach tzw. zwrotu etycznego, wielokrotnie omawianego już

4 F. Nietzsche Poza dobrem i złem, przeł. S. Wyrzykowski, vis-à-vis/Etiuda, Kraków 2010, s. 74.

5 Por. Z. Bauman Etyka ponowoczesna, Aletheia, Warszawa 2012, s. 392; Ch. Taylor Źródła podmiotowości: narodziny tożsamości nowoczesnej, przeł. M. Gruszczyński, T. Gadacz, A. Bielik-Robson, PWN, Warszawa 2012, s. 922-958; R. Rorty Zmierzch prawdy ostatecznej i narodziny kultury literackiej, przeł. A. Szahaj, "Teksty Drugie” 2003 nr 6, s. 113-160.

6 Por. np. M. Januszkiewicz Kim jestem ja, kim jesteś ty?, Wydawnictwo Poznańskie, Poznań 2012, s. 23-36.

7 A. Nasiłowska Historia i etyka, "Teksty Drugie” 2002 nr 1-2, s. 5. 
od strony historycznej, ale także w propozycjach bardziej fragmentarycznych, pojawiających się też na rodzimym gruncie ${ }^{8}$.

Ten drugi aspekt wydaje mi się zresztą istotniejszy, ponieważ mówienie o zwrocie akurat w przypadku problematyki etycznej wydaje mi się co najmniej kontrowersyjne - i to przynajmniej z dwóch powodów (które tutaj mogę niestety tylko zasygnalizować). Po pierwsze, zwłaszcza w polskim kontekście trudno mówić o nadzwyczajnym ożywieniu tego rodzaju badań, a już na pewno ich interpretacyjnych realizacji. Po drugie, zbyt radykalna autonomizacja tematyki moralnej, do czego skłaniałaby perspektywa zwrotu, nieuchronnie skazuje ją na krytykę ze strony „politycznej” (na co wskazuje np. cytowana wcześniej Nasiłowska) i słuszny sceptycyzm ${ }^{9}$ Z tych powodów o wiele przydatniejszą perspektywą wydaje się zatem postrzeganie omawianej tematyki w ścisłym związku z propozycjami dotyczącymi przemian sfery politycznej, na gruncie której etyka może zostać zdefiniowana jako pewien typ relacji podmiotu i wartości określanych jako moralne, a etyczne czytanie - jako interpretacyjne pole pytań o literackie projekty tejże podmiotowości. Pytań, które jednak nie mogą rościć sobie pretensji do transcendentalnego charakteru, ale które są wywodzone ze sfery społecznej i do niej powracają.

Wspomniane zastrzeżenia, mimo krytycznego charakteru, nie dyskredytują zatem samego projektu etycznej lektury, stawiając przed nim jednocześnie wymóg (ciagłej) rekontekstualizacji. Ta zaś, mimo konieczności stosownych wysiłków teoretycznych, powinna być osiągana przede wszystkim performatywnie - tzn. w ramach konkretnych prób interpretacyjnych, a nie dzięki "zaklinaniu" zapewne wciąż niedokonanego zwrotu. Stąd odczytanie Morfiny Szczepana Twardocha w ramach jednej z możliwych perspektyw etycznych (bo oczywiście nie o jedyny właściwy sposób lektury tutaj chodzi - czymś radykalnie odmiennym byłoby odczytanie tej opowieści przez pryzmat myśli

8 Polska refleksja nad etyką literatury wciąż się rozwija i nie można tutaj zapomnieć zwłaszcza o przywołanym w poprzednim przypisie numerze „Tekstów Drugich”, a także m.in.: M. Dąbrowski Projekt krytyki etycznej: studia i szkice literackie, Universitas 2005; P. Mościcki W stronę innego narcyzmu. Literatura, miłość, etyka, "Przegląd Filozoficzno-Literacki” 2006 nr 2, s. 239-259; A. Przyłębski Etyka w świetle hermeneutyki, Oficyna Naukowa, Warszawa 2010; P. Dybel Oblicza hermeneutyki, Universitas, Kraków 2012; M.P. Markowski Polityka wrażliwości: wprowadzenie do humanistyki, Universitas, Kraków 2013; A. Włodarczyk Etyka interpretacji tekstu literackiego. Postmodernizm, humanizm, dydaktyka, Wydawnictwo UJ, Kraków 2014.

9 Z taką krytyczną reakcją spotkały się zwłaszcza propozycje mocno akcentujące niezależność etyki, jak np. J. Hillis Miller Czytanie dokonujace odczytania, w: Dekonstrukcja w badaniach literackich, przeł. P. Wawrzyszko, słowo/obraz terytoria, Gdańsk 2000, s. 125. 
Inności). Morfina w tej perspektywie odsłania interesującą koncepcję podmiotu - borykającego się z własną heterogenicznością (częściowo wynikającą z aspektów jawnie politycznych), a jednocześnie potrzebą samookreślenia się - oraz wizję doświadczenia moralnego polegającego na przechodzeniu między różnymi projektami egzystencjalnymi w ramach decyzji etycznej. W tej interpretacji pomocna okazuje się zwłaszcza myśl Sørena Kierkegaarda i tradycja egzystencjalistyczna, która mocno wpłynęła na współczesne myślenie o podmiotowości.

\section{Osłabianie egzystencjalizmu}

Szukając inspiracji dla ethical reading u Kierkegaarda, warto przyjrzeć się jego własnemu sposobowi czytania, zwłaszcza zaprezentowanemu w Bojaźni i drżeniu, gdzie myśliciel przeprowadził analizę postaci Abrahama i jego zamierzonej, choć niedokonanej, ofiary z syna Izaaka. Duński filozof ukazuje dylemat patriarchy jako sytuację nierozstrzygalną i rozsadzającą ramy racjonalnej etyki (stąd jej ostateczne „teleologiczne zawieszenie”10), wykluczając możliwość prostej deszyfracji sensu moralnego, czego domagałaby się tradycyjna hermeneutyka chrześcijańska. W odróżnieniu do systemów metafizycznych ściśle określających wzór postępowania i ideał osobowy, lektura historii Abrahama skutecznie uniemożliwia przełożenie etyki bohatera na etykę społeczną ${ }^{11}$ :

ze swej strony straciłem dużo czasu na zrozumienie heglowskiej filozofii i wierzę, że zrozumiałem ją dość dobrze, a jeżeli nawet znalazłem w niej pewne miejsca, których nie mogłem zrozumieć, to w mojej naiwności sądzę, że Hegel w tych miejscach sam siebie nie rozumiał. Wszystko to czynię z łatwością, naturalnie i głowa moja na tym nie cierpi. Przeciwnie, gdy tylko pomyślę o Abrahamie, czuję się unicestwiony. W każdym momencie spozieram na ten ogromny paradoks, który jest treścią jego życia, w każdym momencie czuję się odtrącony i myśl moja, mimo całą swą namiętność, nie przenika weń, nie posuwa się ani na włos. Naprężam

10 S. Kierkegaard Bojaźń i drżenie: Choroba na śmierć, przeł. J. Iwaszkiewicz, Homini, Kraków 2008, s. 84-112.

11 Należy zaznaczyć, że rozciągam tutaj pojęcie etyki (rozumianej jako realizacja pewnego projektu egzystencjalnego) również na to, co u Kierkegaarda odpowiada "stadium religijnemu", a nie tylko "stadium etycznemu". 
wszystkie mięśnie, aby zdobyć ogląd tej sprawy, i w tym momencie czuję, jak mnie ogarnia paraliż. ${ }^{12}$

Tym samym Kierkegaard wprowadza typ lektury etycznej, która skupia się na nierozstrzygalności i paradoksalności. Przeciwstawia moralność prywatną, wynikającą z indywidualnego doświadczenia autentycznej prawdy podmiotu, i etykę ogólną - która byłaby możliwa do ujęcia w prawa i maksymy. Filozof dystansuje przez to swoją wykładnię od dostarczania gotowych przykładów moralnych:

Jestem trochę obeznany z tym, co w świecie podziwia się jako wielkie i wspaniałe; dusza moja oswoiła się z tym wszystkim, w całej pokorze pojmuję, że bohaterowie walczą w mojej sprawie, i rozmyślając nad tym wołam do samego siebie: Iam tua res agitur. Potrafię się wmyśleć w bohatera, nie potrafię się wmyśleć w Abrahama, gdy się zbliżam do szczytu, spadam na dół, gdyż to, co tam spotykam, jest paradoksem. ${ }^{13}$

Oczywiście u Kierkegaarda mamy do czynienia z formułą, która zachowuje większy optymizm poznawczy (choć już poważnie ograniczony) niż zdaje się to czynić ponowoczesność, a jak się okaże, również Morfina. Przezwyciężenie metafizycznej etyki oznacza u duńskiego filozofa „skok w wiarę" - zakładając przejście od litery prawa do transcendencji, która choć nie jest dostępna rozumowi, może być doświadczona zmysłem wiary. Tej perspektywy pozbędzie się późniejszy egzystencjalizm, co można dostrzec w słowach Sartre'a:

nie istnieje determinizm, człowiek jest wolny, człowiek jest wolnością. $\mathrm{Z}$ drugiej strony, jeżeli Bóg nie istnieje, nie widzimy przed sobą wartości czy nakazów, które usprawiedliwiałyby nasze postępowanie. Tak więc nie mamy, ani poza sobą, ani przed sobą w dziedzinie wyższych wartości potwierdzenia czy usprawiedliwienia. Jesteśmy sami, nikt nas nie usprawiedliwi. ${ }^{14}$

S. Kierkegaard Bojaźń i drżenie, s. 63. Tamże.

14 J.-P. Sartre Egzystencjalizm jest humanizmem, Warszawskie Wydawnictwo Literackie "Muza",
Warszawa 1998, s. 38-39. 
Oprócz braku oparcia w zewnętrznej instancji podmiot nie znajduje więc fundamentu w samym sobie, nie posiadając uprzednio określonej natury. U Kierkegaarda stan ten najpełniej oddaje charakterystyka stadium estetycznego - gdzie egzystencja jest postrzegana jako czysta możliwość i swobodne przechodzenie między wrażeniami ${ }^{15}$. W Morfinie zaś ta "pustka podmiotu" jest dostrzegalna zwłaszcza w początkowej części historii Konstantego Willemanna.

Wydaje się, że po opisanych przemianach etyczne czytanie w warunkach ponowoczesności musi zmierzyć się z potrójną nieobecnością: całościowego systemu wartości, transcendencji oraz samego podmiotu, odkrywającego swoją bytową heterogeniczność i uwikłanie. W schemacie zaproponowanym przez Kierkegaarda to moment w pół drogi - po teleologicznym zawieszeniu metafizycznej etyki, a przed „skokiem w wiarę", którego niemożliwość John Caputo ${ }^{16}$ uzasadnia nieustannymi wątpliwościami, jakie, chcąc nie chcąc, narzucają się w warunkach ponowoczesności. Dokonujący się mimo wszystko w tej przestrzeni wybór, nieufundowany na uprzednio danych wartościach, jest motywem głęboko zakorzenionym we współczesnej literaturze, a w szczególności w Morfinie. Jej odczytanie pozwala lepiej zrozumieć sytuację ponowoczesnego rozproszenia dyskursów i metafizycznej niesamodzielności podmiotu, której towarzyszy jednocześnie powrót etyki.

\section{Morfina i heterogeniczność}

Kategorią, która pomoże znaleźć płaszczyznę porównania między Morfina i etyką Kierkegaarda, jest szeroko rozumiana wielojęzyczność, pozwalająca scharakteryzować różne rodzaje podmiotowości - zarówno związane z perspektywą opowiadającego (bądź opowiadających), jak i bohaterów. Wielojęzyczność Morfiny przejawia się już w samej narracji - prowadzonej z różnych, zachodzących na siebie i przenikających się perspektyw. Opowiadające głosy, należące do Konstantego, jego matki czy „czarnej bogini”, która zdaje się ogarniać najszerszy obraz i dysponować największą władzą, prowadzą z czytelnikiem grę o nie do końca uchwytnych zasadach. Wywołują

15 Aktualność charakterystyki tego stadium w kontekście ponowoczesności dostrzegła i opisała M. Gołębiewska Wybór etyczny według Kierkegaarda a tożsamość w kulturze medialnej, S. 152-156.

16 Por. J.D. Caputo Against Ethics: Contributions to a Poetics of Obligation with Constant Reference to Deconstruction, Indiana University Press, Bloomington 1993, s. 129-193. 
się nawzajem (chociaż można wśród nich dostrzec pewną hierarchię) i zacierają granice między sobą, co sprawia, że daleko im do narracyjnej autonomii. Z tego powodu do specyficznego układu, jaki proponuje Morfina, można odnieść Bachtinową obserwację na temat twórczości Dostojewskiego: „[...] dialogowe przeciwstawienie leży w centrum utworu. Wszystko jest środkiem, dialog - celem. Jeden głos niczego nie spełnia i nie rozstrzyga. Dwa głosy - to minimum życia, istnienia"17. Polifoniczność jest w książce Twardocha integralną częścią poetyki, która pozwala zaistnieć w narracji różnym historiom - pozornie się dopełniającym i naświetlającym tożsamość tego samego bohatera, Konstantego Willemanna, a w rzeczywistości walczą o dominację (zwłaszcza „czarna bogini” okazuje się bardzo protekcjonalnym i inwazyjnym narratorem) i uzależniają go od siebie, jak tytułowy narkotyk.

Ten złożony i skonfliktowany układ narracyjny prowokuje, by odnieść go do konstrukcji postaci głównego „bohatera” (to określenie, ze względu na przekroczenie w prozie Twardocha paradygmatu mocnej postaci literackiej, w dalszych rozważaniach warto ujmować w przynajmniej myślowy cudzysłów $\left.{ }^{18}\right)$. Pozwoli to lepiej zrozumieć, na czym polega jego szeroko rozumiana wielojęzyczność, która zdecydowanie wykracza poza swoje znaczenie dosłowne - w tym przypadku fakt, oczywiście pozostający nie bez znaczenia, że Konstanty posługuje się swobodnie językiem niemieckim i polskim. Szeroko rozumiane imię własne stawia bohatera na pograniczu tożsamości polskiej i niemieckiej, zwłaszcza ze względu na śląskie pochodzenie matki, Katarzyny Willemann. Choć związała się ona z niemieckim arystokratą i oficerem Baldurem von Strachwitzem, starała się wychować syna na wzorcowego Polaka, w całym schematyczno-modelowym znaczeniu tego słowa. Wydaje się to sprzeczne z jej transgresywną postawą, która potwierdzała się w jej życiowych wyborach - jak się dowiadujemy, przylgnięcie do polskości było „transgresją absolutną"19 (s. 220), przewyższającą stany psychicznego rozchwiania czy seksualne ekscesy. Być może zatem syn był dla niej czymś w rodzaju dzieła sztuki, wytworem estetycznym, który należało doprowadzić

17 M. Bachtin Dialog, język, literatura, red. E. Czaplejewicz, E. Kasperski, PWN, Warszawa 1983, s. 355 .

Willemann wykazuje pewne cechy, które pozwalałyby raczej zaklasyfikować go jako antybohatera, ale tutaj również nie da się wskazać jednoznacznego przełożenia. Por. M. Januszkiewicz W horyzoncie nowoczesności: antybohater jako pojęcie antropologii literatury, "Teksty Drugie" $2010 \mathrm{nr} 3$, s. 60-78. 
do takiej czy innej formy doskonałości, by później go porzucić i zająć się następnymi kreacjami?

Trudno odpowiedzieć na to pytanie, ale z pewnością estetyczny stosunek do rzeczywistości, który można zauważyć w działaniach Katarzyny, głęboko przenika wybory samego Konstantego. Z jednej strony chodzi tutaj o jego artystyczne aspiracje - przejawiające się w manifestowaniu dobrego smaku („Ubranie, żeby pokazać, żem nie byle kto, a jednak byle kto. Żeby chroniło przed rozpadaniem się świata, żeby przypominało, że ja - to nie byle kto" s. 12), studiach filologicznych (polonistycznych, żeby zapomnieć, że „z krwi jest Niemcem" - s. 432), przesiadywaniu ze sławnymi artystami, próbach rysunkowych, fotograficznych, a nawet planach filmowych. Z drugiej strony można mówić o estetycznym sposobie egzystencji czy, używając języka Kierkegaarda, stadium estetycznym, na którym pozostaje bohater, żyjąc „wśród rzeczy skończonych"20 i przechodząc swobodnie od jednych wrażeń do innych. Jego stosunek do nich zdaje się łączyć z poczuciem braku wyjątkowości:

Ja to ja. Jestem Konstanty Willemann, lubię samochody i eleganckie stroje, nie lubię koni, mundurów i nieudaczników. Ja - to nie byle kto. A jednak. Ale to na nic, na nic. Patrzę na siebie w lustrze, ja, to ja, a świata już nie ma i w tym świecie ja to już nie ja, a jeśli nawet ja, to na pewno byle kto. Nawet w ubraniu drogim, w bucikach drogich. Byle kto. Właśnie. (s.12)

Niejako wbrew swojemu imieniu i nazwisku, odsyłającemu z jednej strony do stałości i niezłomności, a z drugiej - do bycia „człowiekiem woli” (czego zresztą zdają się oczekiwać ludzie dookoła niego), Konstanty Willemann rozpoczyna różne egzystencjalne projekty, rezygnując z pełnego zaangażowania się w nie: „Ilu takich ziemia nosi? Półmężczyzn, pół-, a raczej niby-artystów, półojców, półmężów, wszystko po połowie, dość, by zwieść, dość, by wiarygodnie obiecać, nie dość, by obietnic dotrzymać" (s. 66). Bohater daje się prowadzić przez inne osoby, instytucje, zwyczaje, a przy tym sam chce zachować jak najwięcej otwartych możliwości - i przez pierwszą część książki można go definiować głównie przez kategorię potencjalności.

Jego pole możliwości wydaje się bardzo szerokie, jak na warunki okupowanej Warszawy. Konstanty odpowiednio wcześnie zadbał o zabezpieczenie 
materialne dla rodziny, kontakt z Niemcami jest dla niego zupełnie naturalny, a przy tym może liczyć na wrodzony spryt. Po porażce w kampanii wrześniowej potrafi dostosować się do zmieniających się warunków, które sprzyjają takim osobowościom jak on, jednocześnie zachowując możliwie dużo ról, w które może wejść, gdy nadarzy się okazja. Dzięki temu znajduje się w uprzywilejowanej pozycji - rzeczywistość początków okupacji można nazwać okresem liminalnym, w którym już zatarły się stare normy życia społecznego, a jeszcze nie ukształtowały się nowe:

Społeczeństwo rozpuszczone, nie ma Żyda, nie ma Greka, nie ma damy, nie ma kurwy, nie ma profesora ni złodzieja. Towar ze sklepów rozwalonych, z rabunku albo z szabru zwykłego, albo własne futra, stary świat się upłynnił, wyłożony na ulicy w gazetach i kartonach, upłynnił się porządek rzeczy jak rozpuszczony kryształ, futra pożądane zimnym październikiem z właściwych sobie szaf na ulicę [...] (s.13)

I jeśli nawet brak starej hierarchii nie pozwala Konstantemu na bycie „kimś", to przynajmniej towarzyszy mu zadowolenie z lepszego niż inni funkcjonowania w nowych warunkach („Bo jesteś mądry, a ludzie idioci” - s. 15). Można zatem powiedzieć, że jeśli nawet bohater doświadcza kryzysu swojej podmiotowości, to jednocześnie widzi pozytywne strony takiego stanu:

Kim ja jestem? Jestem Konstanty Willemann i lubię kobiety, samochody i morfinę, lubię siedzieć w kawiarniach ze znanymi ludźmi, samemu nie będąc znanym, a jednak siaduję, siadywałem z nimi jak inter pares, co mnie wywyższało ponad nich, bo każdy, kto tam siadywał, musiał się czymś wyróżniać, mało być generałem, trzeba było być Wieniawą, mało poetą, trzeba Tuwima albo Lechonia, a ja pomiędzy nimi siedzę, siedziałem, ja nikt i dlatego ktoś, bo wszyscy wiedzieli, że syn niemieckiego grafa i że się wyrzekł, kto się wyrzekł, a jednak wiedzieli i ta moja nijakość mnie nad nich wywyższała. (s. 463)

Jak widać, labilność i nieokreśloność w płynnej rzeczywistości wojennej mogą stać się nawet przedmiotem pożądania, stanowiąc alternatywę dla bycia jednostką wybitną. Najmniej korzystna dla bohatera okazuje się tożsamość określona, ale przeciętna, ograniczona do prostej społecznej czy politycznej identyfikacji. Konstanty wyczuwa niebezpieczeństwo podpadnięcia pod ogólniejsze kategorie (zbiorowości, wyboru politycznego i szerzej 
- egzystencjalnego), co zresztą w rzeczywistości totalitarnej jest jak najbardziej zrozumiałe. Jest mniej lub bardziej świadomy własnych obaw przed przyjęciem określonej tożsamości bądź zaklasyfikowaniem w niej przez innych. Przykładem jest jeden ze snów Willemanna:

Nad Warszawą wyrasta olbrzymia postać, czarnoszara, wielka niczym drapacz chmur [...], a z jej dłoni niczym promienie spływają na ziemię tysiące srebrnych łańcuszków i delikatne drgnienia tych dłoni kierują tymi łańcuszkami tak, jak drgnieniem wodzy powoduje się koniem. Jeden z łańcuszków spływa do mnie, przyczepiony do mojego kapelusza.

- Das ist ein Deutscher, hört ihr es? Er ist Deutscher! - krzyczy.

Ktoś. Krzyczy. Iga. Szarpie mną, jej dłonie na mojej piersi, pod marynarką, czegoś mnie pozbawiają. - Hier, bitte, das sind seine Papiere. - W jej ręku moja Kennkarte, podaje ją kukiełkom na łańcuszku. Spomiędzy jej włosów łańcuszek. [...]

- Nie jestem Niemcem. Nie jestem Niemcem, rozumiesz? (s. 309-310)

W scenie tej widać, jak skomplikowana okazuje się gra, którą prowadzi Konstanty. Z jednej strony zależy mu na utrzymaniu tożsamości niemieckiej wobec żołnierzy niemieckich. Z drugiej - chce wykazać wobec Igi (pierwszej miłości i byłej narzeczonej), że jego bycie Niemcem jest tylko nominalne i ogranicza się do sfery „papierów”. Podobnie stara się postrzegać również swoją rejestrację w urzędzie i „oficjalne” przyjęcie obywatelstwa Rzeszy (dokonane zresztą na zlecenie polskiej konspiracji). Spotyka przy tym swoją matkę, a konfrontacja z nią uwidacznia jeszcze mocniej egzystencjalną zależność głównego bohatera - podczas gdy on wykonuje zlecenie, zakłada kolejną maskę, dla matki jedynym powodem ponownego stania się Niemką jest jej własna wola.

Dzięki przyjmowaniu (nawet połowicznemu) zewnętrznych projektów egzystencjalnych Konstanty zyskuje doświadczenie, obycie, uznanie, wiarygodność, ale bez poczucia etycznego zaangażowania, za to mocnej doświadcza zależności od innych i heterogeniczności swoich działań. Kolejne wydarzenia podważają możliwość postrzegania jego bogatego uposażenia osobowościowego jako kompetencji społecznej, kulturowej czy egzystencjalnej, zasobu czy rezerwuaru, do którego bohater może sięgać wtedy, kiedy chce. To wewnętrzne, ale obce głosy (zwłaszcza „czarnej bogini”) podpowiadają mu, co ma zrobić, kierują kolejnymi krokami Konstantego i tak naprawdę opowiadają jego historię. Dlatego Morfina odsyła raczej do pytania, jak różnorodne języki, 
dyskursy i narracje posługują się nim, tworzą jego tożsamość i wyznaczają pole możliwości, z których może korzystać.

\section{Nieja}

Konstrukcja podmiotowości głównego bohatera, opartej na potencjalności, otwarciu i niedookreśleniu, wymaga szczególnej uwagi. Sposób, w jaki Konstanty wchodzi w swoje role, nakładając kolejne maski, dąży w przeciwnym kierunku niż zjawisko narastania czy sedymentacji cech postaci literackiej, opisane przez Henryka Markiewicza:

Przeważnie [...] mówiąc o postaci literackiej mamy na myśli nie [...] „nagi" podmiot, lecz indywidualny antropomimetyczny układ cech jakościowych. Układ ten jest tylko częściowo dany przy wprowadzeniu postaci; w miarę narastania tekstu stopniowo się wytwarza, wzbogaca, utrwala i uwyraźnia (przez powtórzenia manifestacji określonej cechy), czasem modyfikuje (przy czym dane uprzednie mogą ulec reinterpretacji lub nawet zasadniczej zmianie). [...] Tak rozumiana postać powstaje na podstawie tekstu, jest w nim zakorzeniona, ale dana jest w nim co najwyżej częściowo $[\ldots]^{21}$

W Morfinie główny bohater, nawet jeśli z początku postrzegamy go jako silną osobowość, oczywiście „częściowo daną” i niedookreśloną, zamiast stopniowo nabierać bardziej wyrazistych cech, zaczyna roztapiać się i rozmywać wśród kolejnych głosów, dołączających się do narracyjnej polifonii. Zbiega się to z tendencjami w literaturze nowoczesnej i ponowoczesnej zaobserwowanymi przez Edwarda Kasperskiego:

Esse postaci, czyli samoistne istnienie, zamienia się w esse percipi, w sposób jej postrzegania, punkt widzenia i perspektywę, w jakiej się ona pojawia, w relację prezentującą postać. W konsekwencji postacie stają się „widziadłami", bytami postrzeżeniowymi oraz relacjami z postrzeżeń $[\ldots]^{22}$

H. Markiewicz Wymiary dzieła literackiego, Wydawnictwo Literackie, Kraków-Wrocław 1984, s. 154 . 
Byt Konstantego z pewnością jest dość widmowy, podobnie jak sposób jego funkcjonowania i działania w trybach historii. Jak podsumowuje narratorka, „[...] musiałbyś wiedzieć, kim jesteś, Kosteczku. A ja ci tego nie powiem, bo ja sama tego nie wiem, patrzę na ciebie tak długo, mój kochany, i widzę szarą plamę, chaos" (s. 159). Ta negatywna nieokreśloność, paraliżująca i dezorientująca, różni się od nieokreśloności silnych postaci (matki czy Dzidzi) tym, że nie stanowi zasłony dla „czarnej bogini” i może być z powodzeniem poddawana manipulacji, wbrew woli samego bohatera.

Mówiąc językiem narratologii Mieke Bal, w Morfinie na plan pierwszy wysuwa się napięcie między „mocami” (to metaforyczne określenie jest tutaj wyjątkowo trafne) i ich ,adresatem", których badaczka definiuje w ten sposób:

Zamiar podmiotu sam w sobie nie wystarcza, by osiągnąć cel. Zawsze istnieją moce, które albo na to pozwalają, albo temu zapobiegają. Ta relacja może być postrzegana jako forma komunikacji, w związku z czym możemy wyróżnić pewną kategorię aktorów: tych, którzy wspierają podmiot w realizacji zamiarów, dostarczają dopełnienia lub pozwalają je dostarczyć bądź podarować - będziemy ich określać jako moc [power]. Osobę, której „dostarcza się" dopełnienia, nazywamy adresatem. ${ }^{23}$

Konstanty nie tylko otrzymuje „dopełnienia”, ale popada w uzależnienie od nich. Oczywiście "moc często nie jest osobą, ale abstraktem: na przykład społeczeństwem, przeznaczeniem, czasem, ludzkim egocentryzmem lub sprytem"24 i także w Morfinie chodzi o bardzo różne czynniki - ojca, matkę (która sama przejawia się na różne sposoby - postaci, narratorki), „czarną boginię", szeroko rozumianą niemieckość, polskość, historię, nałóg, Helę, Salome i wiele innych. To właśnie moce, wspierające, ale i opanowujące działania Konstantego, tworzą jego wielojęzyczność jako specyficzny sposób istnienia podmiotowości, opierający się na wielości głosów przemawiających w nim i przez niego. On sam, jego osobisty wybór, zdaje się ginąć w tej różnorodności, co jak wskazuje Kierkegaard, jest charakterystyczne dla estetycznego stosunku do świata:

23 M. Bal Narratologia. Wprowadzenie do teorii narracji, przeł. E. Krzempek et al., red. E. Kraskowska, E. Rajewska, Wydawnictwo UJ, Kraków 2012, s. 205. 
Jeśli człowiek patrzy sam na siebie przez pryzmat estetyki, wówczas uświadamia sobie swoją jaźń w postaci wewnętrznie określonego, wielorako zróżnicowanego konkretnego bytu, ale wbrew całej tej wewnętrznej różnorodności wszystko to razem wzięte stanowi jego istotę, mając jednakie prawo do ujawnienia się i równe prawo do wcielenia w życie. Jego dusza podobna jest do gruntu, z którego wyrosły najprzeróżniejsze rośliny, mające wszystkie jednakie prawo do tego, aby dojrzeć; jego jaźń to ta właśnie różnorodność, a on nie ma innej jaźni ponad tę właśnie. $^{25}$

Właściwie aż do czasu egzystencjalnego przełomu, który następuje w dalszej historii bohatera, te głosy zdecydowanie nad nim dominują, prowokując nawet pytanie, czy można w ogóle mówić o indywidualnej tożsamości bohatera - a więc swoistym idiolekcie wśród słyszalnych w narracji języków, których genealogię stopniowo poznaje czytelnik. Nietrudno przy tym zauważyć, że niektóre z nich wchodzą w konflikt (w kontekście czasu akcji powieści dotyczy to szczególnie ról Niemca i Polaka), co jeszcze bardziej osłabia znaczenie indywidualnej historii Konstantego wobec konfliktu dyskursów, które za jego pomocą rozgrywają własną walkę.

Czy to znaczy, że Konstanty jest postacią zupełnie drugorzędną wobec toczącej się intrygi? Nie do końca, ponieważ to głównie jego działania popychają akcję naprzód. Jednak paradoksalnie w gestach, przez które bohater zdaje się panować nad rzeczywistością, ujawnia się jego niesamodzielność, co dobrze widać w następującym dialogu (który jest jednocześnie dialogiem perspektyw narratorskich):

Czym mogę mu zagrozić, skoro nie ma w nim strachu przed niczym? Musisz teraz być Niemcem, Konstanty. Żeby odnaleźć teczkę, ocalić siebie jako Polaka, musisz stać się teraz Niemcem. Niemcem. Zaufaj mi, Konstanty, jestem twoją jedyną przyjaciółką. (s. 138)

Czy ja naprawdę zrobiłem to, co zrobiłem? Kto prowadził moją dłoń, małe ostrze dotyka czerwonego kącika spojówki, wsuwa się pod powiekę, skąd mam tyle siły, Tumanowicz szarpie się przecież, a ja lewą dłonią ściskam jego czaszkę, ani drgnie, a małe ostrze krąży, drapie o kość i zrywa wątłe włókna, skąd mam siłę taką, aby pode mną ani drgnął? (s. 142) 
"Niemieckość", choć oznacza siłę i dominację, wiąże się tutaj z dotkliwym doświadczeniem alienacji wobec własnego działania. Poddanie się wewnętrznemu dyskursowi jest podobne do zażywania morfiny, umożliwia wykroczenie poza siebie, ale czyni zderzenie z realnością tym bardziej problematycznym, ponieważ daje Konstantemu odczuć jego niesamodzielność. Brak autonomii to z kolei jedno z imion nowoczesnego kryzysu podmiotowości - a Morfina na swój sposób wpisuje się w nurt literatury, który ukazuje i radykalizuje przekonanie, że

[...] podmiotu nie sposób już traktować jako istniejącego i funkcjonującego niezależnie i uprzednio wobec różnego rodzaju intersubiektywnych struktur i kontekstów, w których się przejawia, takich jak język, struktury historyczne, społeczne, mentalne. ${ }^{26}$

W przypadku omawianego bohatera jest to zależność bardzo skrajna, powodująca mocne poczucie alienacji i pogłębiająca się. Pluralizacja i wielość języków, jakie mogą wchłonąć podmiotowość Konstantego, nie ma właściwie kresu, oprócz sytuacji, gdy bohater zostanie przyswojony do końca:

Całe życie rozmieniasz się na drobne. Kosteczku, wiesz o tym. Te twoje obrazki, których nikt nie chce, sam ich nawet nie chcesz, wysiadywanie po kawiarniach, romanse, to wszystko jak struganie duszy, strugasz ją, wióry lecą na podłogę, a dusza ci cienieje, Kosteczku, aż w końcu zestrugasz się cały, nic nie zostanie. (s. 159)

Z tego mechanizmu zależności nie wyzwala nawet śmierć, ponieważ wraz z jej przyjściem kończy się wprawdzie narracja subiektywna, ale rolę opowiadacza już w całości przejmuje „czarna bogini” (historia?). Jej władzę w powieści odzwierciedlają liczne ekskursy na temat ważniejszych lub mniej ważnych postaci. Konstanty jest więc w swoim zwyczajnym toku egzystencji na najlepszej drodze, by całkowicie zatracić się w cudzych dążeniach i narracjach, bez względu na to, jak „bohaterskich” i „wielkich” (z zewnętrznej perspektywy) czynów mógłby dokonać.

26 A. Zawadzki Autor. Podmiot literacki, w: Kulturowa teoria literatury, red. M.P. Markowski, R. Nycz, Universitas, Kraków 2010, s. 222. 


\section{Oczy otwieram}

W historii Konstantego następuje istotna przemiana, której warto przyjrzeć się bliżej. Dokonuje się ona podczas podróży z Dzidzią Rochacewicz, która osobowościowo jest bardzo podobna do matki bohatera. Jest niezależna, silna, ironiczna, a przede wszystkim kształtuje własną tożsamość za pomocą wyborów, z którymi się identyfikuje i których nie podporządkowuje innym (dlatego np. z taką swobodą sama proponuje tymczasową "maskę" prostytutki towarzyszącej Konstantemu). Nie znaczy to, że nie potrzebuje dopełnienia (w rozumieniu Mieke Bal), ale przyjmuje je na własnych zasadach. Ten egzystencjalny projekt dobrze odzwierciedlają słowa skierowane do bohatera: „mógłbyś żyć sobą samym, nie innymi” (s. 462).

Willemann z początku jest zupełnie zdezorientowany jej osobą - nie potrafi przyporządkować jej do żadnego dotychczasowego klucza (zwłaszcza seksualnego), który służył mu w relacjach z kobietami. Odnajduje jedynie pewne podobieństwo z matką - „siłę głosu” (por. s. 447), który kojarzy z pewnego rodzaju „szlachectwem ducha”, zależącym nie od arystokratycznego pochodzenia, ale siły osobowości. Jednak w odróżnieniu od Katarzyny Willemann Dzidzia nie chce uczynić Kostka swoim dziełem sztuki. Dzięki temu daje mu okazję uświadomienia sobie pustki i etycznej niesamodzielności.

Bohater zdaje się korzystać z tej szansy, a raczej odkrywa w sobie możliwość jej dokonania. Charakterystyczna jest tutaj scena przed lustrem i nieco monotonna, ale istotna litania autoidentyfikacji, stanowiąca kontrapunkt dla analogicznej sceny początkowej:

Patrzę w lustro. Jestem Konstanty Willemann i nie jestem morfinistą. Jestem Konstanty Willemann i nie jestem we władzy mojej matki. Jestem Konstanty Willemann i nie jestem we władzy mojego ojca ani jego ducha, upiora, który wisiał nad moim dzieciństwem i młodością. Poprawiam węzeł krawata, podciągam go trochę do góry, aby ładnie wystawał, poprawiam fałdkę. Jestem Konstanty Willemann i nie włada mną żadna kobieta. Jestem Konstanty Willemann i nie jestem na niczyjej służbie. Jestem Konstanty Willemann i nie służę Polsce, nie służę Niemcom, nie służę Bogu ani diabłu, nie służę nikomu. Jestem Konstanty Willemann i nie jestem żołnierzem, nie jestem oficerem, jestem Konstanty Willemann. Nie jestem dobry. Nie jestem zły. Jestem Konstanty Willemann. (s. 543) 
Przywołany wcześniej Kierkegaardowski wzorzec kusi, by po prostu zastosować go do tej przemiany i uznać, że Konstanty zmienił swój estetyczny stosunek i wszedł w stadium etyczne. Jednak sprawa nieco się komplikuje, gdy dostrzeżemy, że wśród wymienionych abnegacji znajdują się także te dotyczące dobra i zła. Nieprzypadkowo filozof pyta: „[... ] czy ten, kto wybrał siebie w sposób absolutny, mógłby bez zastrzeżeń powiedzieć: teraz jestem panem samego siebie, więcej nie żądam, a całej zmienności świata przeciwstawiam tę dumną myśl: «jestem tym, kim jestem»?"27. Tymczasem właśnie ta prosta afirmacja zdaje się leżeć u źródeł przemiany Willemanna, który nie chce „podporządkować się czynnikom podlegającym konieczności”, jak chciałby Kierkegaard. Być może oznaczałoby to właśnie podporządkowanie się perspektywie „czarnej bogini”. Tajemnicza narratorka sama przyznaje, że boi się Dzidzi (reprezentującej skrajnie indywidualistyczny sposób bycia), a na czas jej podróży z Konstantym opuszcza go, by powrócić dopiero przy tragicznym końcu - absurdalnej, pozbawionej wzniosłości i znamion bohaterstwa śmierci.

\section{Jestem Konstanty Willemann czy jestem Konstantym Willemannem?}

Decyzje podejmowane przez Konstantego po jego przemianie, zwłaszcza opuszczone ostatecznie przez ich „autora”, mogą zostać wpisane w narrację patriotyczną, poddaną kategorii obowiązku i kodeksu walki z wrogiem. Jednak sam bohater opiera się nie na wyborze deontologicznej konieczności, ale osobistej etyki, odwołującej się do przygodności istnienia, w którym „tylko na wierzchu szuka się odpowiedzi na pytanie «dlaczego»" (s. 579). Takie rozumienie moralności to kolejny z wielu momentów, gdy Twardoch zdaje się stylizować czasy wojenne zgodnie ze specyfiką ponowoczesności.

Historia Konstantego prowadzi do równie poważnej, co Kierkegaardowska przemiany stosunku bohatera do świata. Można ją nazwać, zgodnie z przyjętą wcześniej metaforyką, przejściem od wielojęzycznej zależności do względnej, bo tylko chwilowej, autonomii i próby zabrania głosu wśród konstytuujących podmiotowość dyskursów. Niemniej ta autonomia jest powieści Twardocha dwuznaczna, ponieważ ostatecznie skutkuje wymazaniem odtrącającej ją indywidualności z wielkiej historycznej narracji. Zarysowana ewolucja postaci Konstantego jest ruchem przeciwko dyskursywnej kolonizacji jednostki, ale pozytywny, konstruktywny wymiar tego procesu zostaje 
zakwestionowany przez brak samodzielnego, autentycznego określenia się Konstantego w ramach którejś z opowieści. Bohater, dzięki odrzuceniu „zewnętrznych" identyfikacji, dochodzi do ograniczonej (i chwilowej) władzy nad własną wewnętrznością czy raczej: do względnego upodmiotowienia się w niej ${ }^{28}$. Dzięki temu może dokonywać wyborów, które można nazwać etycznymi w rozumieniu ponowoczesnym, opisywanym przez Baumana:

Powołanie moralne jest z gruntu osobiste. Wezwanie - jeśli można mówić o wezwaniu - zwraca się do mojej odpowiedzialności; pobudki, by wziąć troskę i dbałość na siebie, nie uciszy ani nie uśmierzy poczucie, że inni ludzie zrobią to za mnie albo że - jeśli o mnie chodzi - zrobiłem już to, co na mnie wedle ogólnie przyjętych standardów przypadało. [...] W braku norm powszechnych mój, podmiotu moralnego, los jest o wiele bardziej uciążliwy. ${ }^{29}$

Z pewnością Morfina, poddana etycznej lekturze, nie może stać się ani kodeksem moralności patriotycznej, ani opowieścią o wielkości człowieka i sile jego autonomicznej wolności. Z punktu widzenia interpretatora odrębność losu Konstantego okazuje się podobna do odrębności Abrahama - nie da się jej naśladować ani przełożyć na ogólne kategorie:

Nie mogę zrozumieć Abrahama; w pewnym sensie nie mogę się niczego nauczyć od niego, zdumiewam się tylko. Jeżeli sobie człowiek wyobrazi, że rozmyślając nad wynikiem tej historii, może zacząć wierzyć, to oszukuje siebie i oszukuje Boga co do pierwotnej pobudki wiary. ${ }^{30}$

Podstawowa różnica polega na tym, że lektura etyczna, tak jak ją proponował Kierkegaard, zostaje w ponowoczesności osłabiona przez niemożliwość pozatekstowej sceny, na której dokonywałoby się spotkanie z transcendencją. W Konstantym zachodzi przemiana, jednak wykorzenienie jego wewnętrzności z jakiegokolwiek zewnętrznego projektu aksjologicznego sprawia, że nie da się go uczynić „rycerzem wiary” (w Boga, rozum, historię, naród), którego

28 Rekonfiguracja relacji między podmiotowością i wewnętrznością według Charlesa Taylora okazuje się czynnikiem konstytuującym w ogóle podmiotowość nowoczesną (por. Ch. Taylor Źródła podmiotowości..., s. 212-387). 
poszukiwała modernitas. Paradoksalnie, mimo wyjścia z paradygmatu estetycznego, jego podmiotowość nadal pozostaje „pusta” - niemniej zdolna do podejmowania wyboru moralnego, nawet jeśli jest on pozbawiony metafizycznego fundamentu.

Wreszcie można powiedzieć, że w podobnej sytuacji pozostaje także interpretator, który mierzy się z etycznym wymiarem Morfiny, stanowiącej pod tym względem dość paradoksalne wyzwanie. Trudno byłoby odwołać się w tej sytuacji do jakiegoś zewnętrznego kodeksu, nie popadając we wspomniane na samym początku „moralizowanie” - ponieważ sama strategia powieści opiera się właśnie na niemożliwości ustalenia motywacji bohatera, za którymi można by podążać. Tekst nie oferuje czytającemu czegoś, co zapełni podmiotową pustkę - a jednocześnie apeluje do samej egzystencjalnej zdolności kreowania i wybierania wartości. Eksponując wielojęzyczność i heterogeniczność podmiotu moralnego, nie przekreśla przy tym politycznego uwikłania „ja” - nieco wbrew tradycji egzystencjalistycznej, ale zdecydowanie w duchu ponowoczesnym.

\section{Abstract}

\section{Michał Koza}

JAGIELLONIAN UNIVERSITY (CRACOW)

'Not-I Open my Eyes': Ethical Reading and Szczepan Twardoch's Morphine

This paper explores the possibilities of an ethical reading of Szczepan Twardoch's Morphine in the wider context current notions of the ethics of literature. Koza's aim is to show how ethical interpretations relate to the postmodern concept of subjectivity with its broadly understood 'multilinguality'. In the case of Twardoch's novel, this 'multilinguality' is particularly evident in the construction of the narrator and characters. The use of a methodology peculiar to interpretations inspired by existentialism, mainly Kierkegaardian ones, enables Koza to outline the characters' ethical situation, as well as the axiology of the very act of interpretation.

\section{Keywords}

the ethics of literature, existentialism, Kierkegaard, subjectivity, axiology 